\title{
Documentation of Ancestral Caddo Ceramic Vessels from Sites in Red River County, Texas
}

Timothy K. Perttula

Heritage Research Center, Stephen F. Austin State University

Follow this and additional works at: https://scholarworks.sfasu.edu/ita

Part of the American Material Culture Commons, Archaeological Anthropology Commons, Environmental Studies Commons, Other American Studies Commons, Other Arts and Humanities Commons, Other History of Art, Architecture, and Archaeology Commons, and the United States History Commons

Tell us how this article helped you.

This Article is brought to you for free and open access by the Center for Regional Heritage Research at SFA ScholarWorks. It has been accepted for inclusion in Index of Texas Archaeology: Open Access Gray Literature from the Lone Star State by an authorized editor of SFA ScholarWorks. For more information, please contact cdsscholarworks@sfasu.edu. 
Documentation of Ancestral Caddo Ceramic Vessels from Sites in Red River County, Texas

\section{Creative Commons License}

\section{(c) (1) \&}

This work is licensed under a Creative Commons Attribution-NonCommercial 4.0 International License 


\title{
Documentation of Ancestral Caddo Ceramic Vessels from Sites in Red River County, Texas
}

\author{
Timothy K. Perttula
}

\section{Introduction}

The vessel collections at the Texas Archeological Research Laboratory at The University of Texas (TARL) have ancestral Caddo vessels from a number of sites along the Red River in the Mound Prairie area. Vessels are documented in this article from four such sites, including Wright Plantation (41RR7), Howard Hampton Farm (41RR10), Sam Kaufman (41RR16), and the Abe Cox Place (with no trinomial), in the vicinity of the Rowland Clark site (41RR77) (Figure 1). I also discuss a small ceramic sherd assemblage at TARL from the Wright Plantation site.

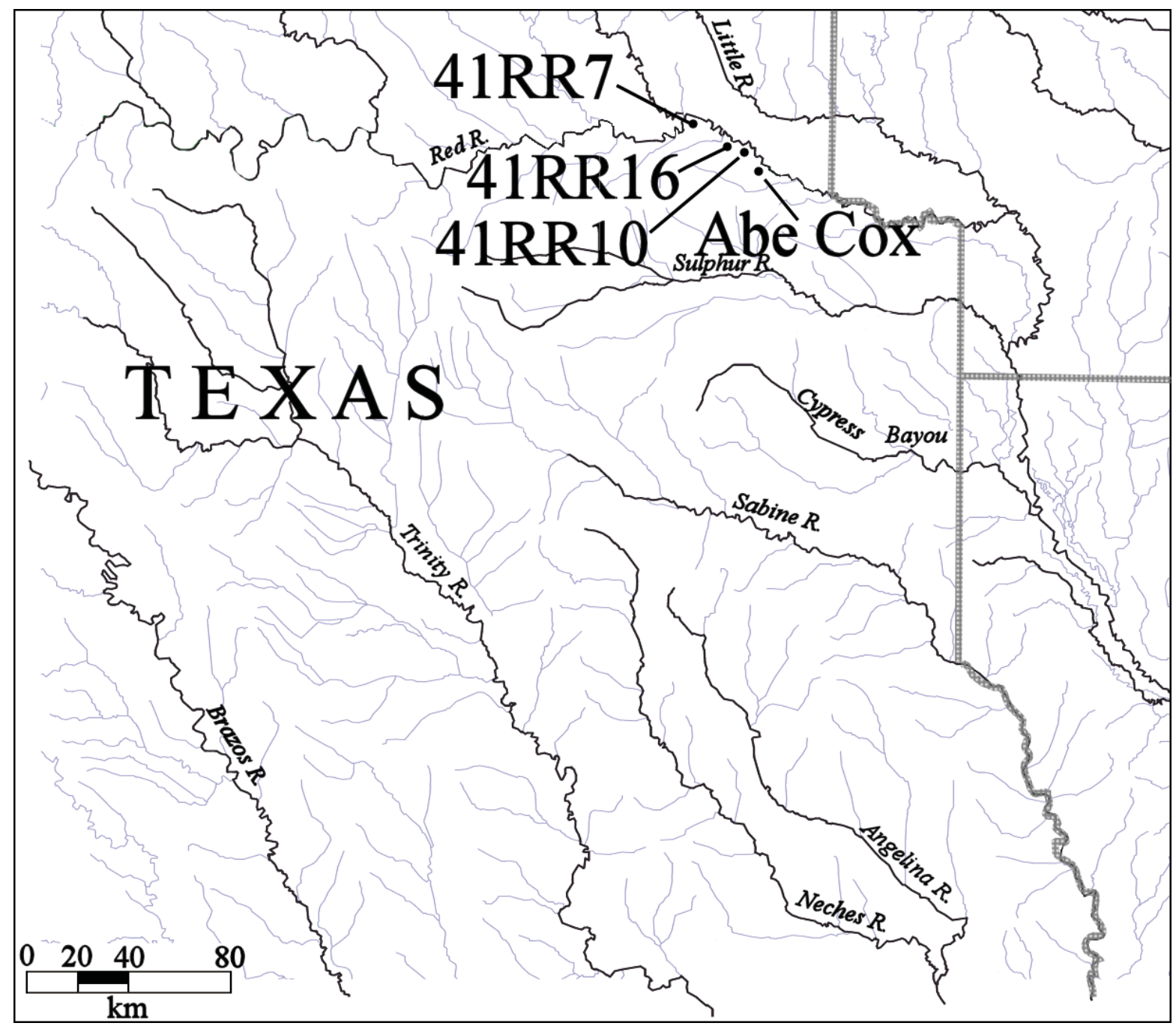

Figure 1. Locations of sites mentioned in the article on the Red River in Northeastern Texas. 


\section{Sites and Vessels}

\section{Wright Plantation (41RR7)}

The Wright Plantation site is a multiple mound center on the Red River, about $1 \mathrm{~km}$ north of the Fasken site (41RR14), another multiple mound center (Prikryl 2008), and $7 \mathrm{~km}$ upstream from the Sam Kaufman site (41RR16), a very large village with two constructed mounds and several discrete cemeteries (Perttula 2008). The site has both Mounds Prairie and McCurtain phase occupations at the site, and at least one of the mounds at Wright Plantation appears to have been constructed and used as a burial mound during the McCurtain phase. During the 1930s, the landowner, George Wright, recovered many ceramic vessels from this mound (Mound B), and this collection is now in the holdings of the University of Oklahoma's Sam Noble Oklahoma Museum of Natural History.

The collections from TARL have three ancestral Caddo ceramic vessels from the Wright Plantation site on the George Wright Farm; their specific provenience is not known. They were donated in the 1930s to the University of Texas by W. A. Rikard, a local avocational archaeologist. They include a portion of a shell-tempered jar, a grog-tempered Wilder Engraved bottle that was likely obtained in trade or exchange from a Titus phase group living in the Big Cypress or Sabine River basins 50+ miles south of the Red River, and a Crockett Curvilinear Incised olla or short-necked bottle.

SITE NAME OR SITE NUMBER: Wright Plantation (41RR7)

VESSEL NO.: 77 (W. A. Rikard Collection)

VESSEL FORM: Jar

NON-PLASTICS AND PASTE: shell

RIM AND LIP FORM: N/A

CORE COLOR: F (fired in a reducing environment and cooled in the open air, see Teltser 1993:Figure 2f)

INTERIOR SURFACE COLOR: reddish-brown; fire clouds on the body and base

EXTERIOR SURFACE COLOR: reddish-brown; fire clouds on the body

WALL THICKNESS (IN MM): body, $5.1 \mathrm{~mm}$

INTERIOR SURFACE TREATMENT: none

EXTERIOR SURFACE TREATMENT: none

HEIGHT (IN CM): 9.7+

ORIFICE DIAMETER (IN CM): 13.4

DIAMETER AT BOTTOM OF RIM OR NECK (IN CM): N/A

BASE DIAMETER (IN CM) AND SHAPE OF BASE: $6.4 \mathrm{~cm}$, circular and flat

ESTIMATED VOLUME (IN LITERS): $0.8+$

DECORATION (INCLUDING MOTIF AND ELEMENTS WHEN APPARENT): Plain 
PIGMENT USE AND LOCATION ON VESSEL: none

TYPE AND VARIETY (IF KNOWN): Unknown plain ware

SITE NAME OR SITE NUMBER: Wright Plantation (41RR7)

VESSEL NO.: 78

VESSEL FORM: Bottle

NON-PLASTICS AND PASTE: fine grog

RIM AND LIP FORM: Direct rim; lip not present

CORE COLOR: G (fired in a reducing environment and cooled in the open air, see Teltser 1993:Figure 2g)

INTERIOR SURFACE COLOR: dark grayish-brown

EXTERIOR SURFACE COLOR: yellowish-brown; fire clouds on the rim and body

WALL THICKNESS (IN MM): rim, $5.7 \mathrm{~mm}$

INTERIOR SURFACE TREATMENT: none

EXTERIOR SURFACE TREATMENT: burnished

HEIGHT (IN CM): 10.8

ORIFICE DIAMETER (IN CM): 3.7

DIAMETER AT BOTTOM OF RIM OR NECK (IN CM): $4.8 \mathrm{~cm}$; maximum body diameter: $11.5 \mathrm{~cm}$

BASE DIAMETER (IN CM) AND SHAPE OF BASE: $5.0 \mathrm{~cm}$, circular and flat

ESTIMATED VOLUME (IN LITERS): 0.2

DECORATION (INCLUDING MOTIF AND ELEMENTS

WHEN APPARENT): The vessel body has four sets of curvilinear and intertwined scroll lines that have enlarged cross-hatched zones where upper and lower scroll lines pass each other (Figure 2). Each upper and lower engraved scroll line begins at the apex of large cross-hatched pendant triangles with central negative circles. At the upper end of the vessel body, the large pendant triangles are embedded in a narrow horizontal engraved band with cross-hatched lines.

PIGMENT USE AND LOCATION ON VESSEL: red pigment in the engraved lines

TYPE AND VARIETY (IF KNOWN): Wilder Engraved, var. Wilder

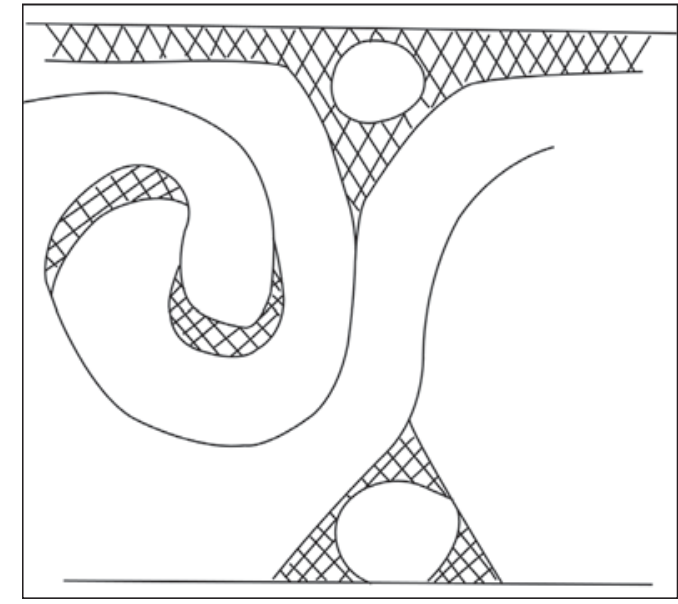

Figure 2. Decorative elements on Wilder Engraved, var. Wilder bottle (No. 78) from the Wright Plantation site (41RR7). 
SITE NAME OR SITE NUMBER: Wright Plantation (41RR7)

VESSEL NO.: No Number, W. A. Rikard Collection

VESSEL FORM: Olla or short-necked bottle

NON-PLASTICS AND PASTE: grog

RIM AND LIP FORM: Direct rim and flat lip

CORE COLOR: A (fired and cooled in an oxidizing environment, see Teltser 1993:Figure 2a)

INTERIOR SURFACE COLOR: yellowish-brown; fire clouds on the body

EXTERIOR SURFACE COLOR: yellowish-brown; fire clouds on the rim

WALL THICKNESS (IN MM): rim, $8.1 \mathrm{~mm}$; body, $5.7 \mathrm{~mm}$

INTERIOR SURFACE TREATMENT: none

EXTERIOR SURFACE TREATMENT: none

HEIGHT (IN CM): N/A

ORIFICE DIAMETER (IN CM): 8.0

DIAMETER AT BOTTOM OF RIM OR NECK (IN CM): 9.5; maximum body diameter, $15.2+\mathrm{cm}$

BASE DIAMETER (IN CM) AND SHAPE OF BASE: N/A

ESTIMATED VOLUME (IN LITERS): N/A

DECORATION (INCLUDING MOTIF AND ELEMENTS WHEN APPARENT): The vessel body has at least one (and probably four) central incised circle element filled with small punctations (Figure 3). There are a series of concentric incised lines around the central circle, and horizontal and diagonal incised lines connecting the central circle elements.

PIGMENT USE AND LOCATION ON VESSEL: none

TYPE AND VARIETY (IF KNOWN): cf. Crockett Curvilinear Incised

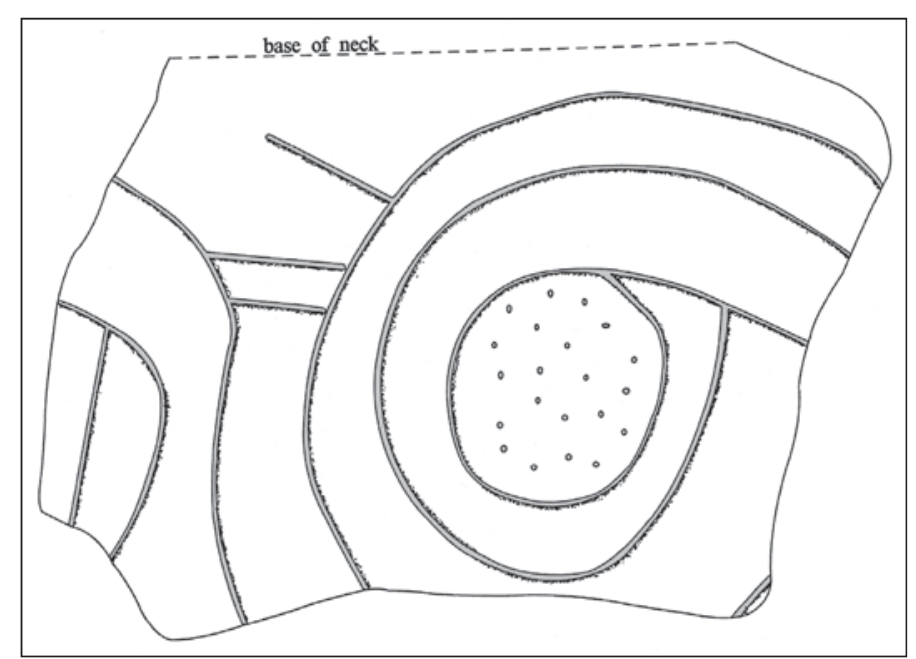

Figure 3. Decorative elements on Crockett Curvilinear Incised olla or short-necked bottle from the Wright Plantation site (41RR7). 


\section{Ceramic Sherd Assemblage at the Wright Plantation Site}

The ceramic sherds in the TARL collections from the Wright Plantation site were primarily donated in 1930 by George T. Wright, and likely came from a surface collection when the site was being plowed. One distinctive engraved sherd was donated to the University of Texas in March 1942.

The 61 sherds in the collection from the site are from plain ware, utility ware, and fine ware vessels tempered with either shell, grog, grog-hematite, and bone (Table 1). About 65.6 percent of the sherds (and 61.9 percent of the decorated sherds) are from vessels tempered with crushed and burned mussel shell; these are from vessels made by Late Caddo period McCurtain phase (ca. A.D. 1400-1700) potters. The remainder of the sherds are likely from the ca. A.D. 1000-1200 Early Caddo period component that is represented by at least the previously mentioned Crockett Curvilinear Incised vessel, and by sherds from primarily grog-tempered vessels.

Table 1. Ceramic sherd assemblage.

\begin{tabular}{lllcll}
\hline Ware & \multicolumn{5}{c}{ Temper Categories } \\
& Shell & Grog & Grog-hematite & Bone & N \\
\hline Plain & 27 & 9 & 1 & 3 & 40 \\
Utility & 5 & 2 & - & - & 7 \\
Fine & 8 & 6 & - & - & 14 \\
\hline Totals & 40 & 17 & 1 & 3 & 61 \\
\hline
\end{tabular}

The shell-tempered utility ware sherds from the Wright Plantation site include body sherds from Nash Neck Banded or Emory Punctated-Incised vessels with parallel or straight appliqued fillets on the bodies of jars, along with Emory Punctated-Incised vessels with rows of punctations on vessel rims as well as bodies (Table 2). The one parallel trailed sherd is from a Foster Trailed-Incised vessel.

Table 2. Decorative Methods and elements in the utility ware and fine ware sherds from the Wright Plantation site.

\begin{tabular}{llll}
\hline Decorative method and element & Rim & Body & $\mathrm{N}$ \\
\hline
\end{tabular}

\section{Shell-tempered}

\section{Utility Ware}

\section{Appliqued}

parallel appliqued fillets

straight appliqued fillet

\section{Punctated}

fingernail punctated rows

tool punctated row

$\begin{array}{lll}- & 1 & 1 \\ - & 1 & 1 \\ - & & \\ - & 1 & 1 \\ & 1 & 1\end{array}$

\section{Trailed}

Parallel trailed lines

$-$ 
Table 2. Decorative Methods and elements in the utility ware and fine ware sherds from the Wright Plantation site, cont.

\begin{tabular}{llll}
\hline Decorative method and element & Rim & Body & $\mathrm{N}$ \\
\hline
\end{tabular}

\section{Shell-tempered}

\section{Fine Ware}

Engraved-red-slipped curvilinear hatched zones-int./ext. red-slipped parallel engraved lines-int. red-slipped

Red-slipped

int./ext. red-slipped

Trailed

straight trailed line

$\begin{array}{lll}- & 1 & 1 \\ - & 1 & 1 \\ - & & \\ & 2 & \end{array}$

Trailed-Incised

curvilinear trailed lines and hatched incised zone

$\begin{array}{ll}- & 2\end{array}$

2

Grog, grog-hematite, and bone-tempered

Utility Ware

Appliqued-punctated

appliqued node and fingernail punctated rows

1

1

Incised

straight incised line

$\begin{array}{ll}- & 1\end{array}$

1

\section{Fine Ware}

Engraved small circle el.

horizontal engraved lines

\begin{tabular}{lll}
- & 1 & 1 \\
2 & 1 & 3 \\
- & 1 & 1 \\
- & 1 & 1 \\
\hline 2 & 19 & 21
\end{tabular}

Engraved-red-slipped

curvilinear engraved lines and excised triangle el.-ext. red-

slipped

straight engraved line-int./ext. red-slipped

Totals

The shell-tempered fine ware body sherds in the assemblage are represented by a red-slipped Avery Engraved body sherd with narrow curvilinear hatched zones (Figure 4c), another possible Avery Engraved sherd with parallel engraved lines and red-slipped surfaces, and two sherds from Clement Redware vessels (see Flynn 1976). The other shell-tempered fine wares include two body sherds from Keno Trailed vessels and two sherds from Hudson Engraved (e.g., trailed-incised elements) vessels (Figure 4b). One of the grog-tempered sherds is from a Hatinu Engraved bottle (Figure 4d), an early historic Red River basin type (Perttula and Selden 2014:46 and Plate 37). The sherd has a zone of redslipping defined by areas to either side where the red slipped surface has been scraped away, along with straight and curvilinear engraved lines and a curvilinear excised triangle element engraved through the red-slipped zone. 

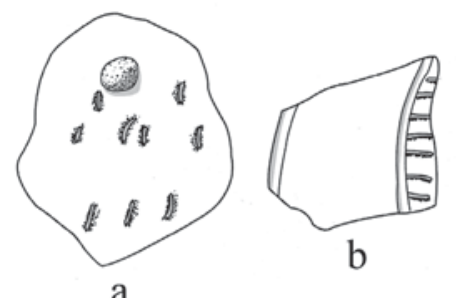

a

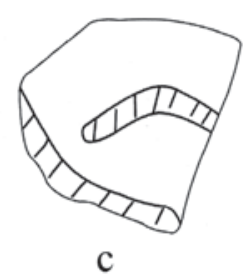

C

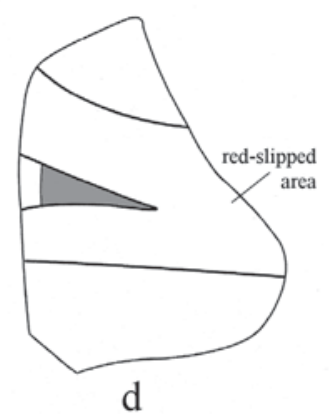

Figure 4. Selected decorative methods and elements in utility ware and fine ware sherds in the Wright Plantation site assemblage.

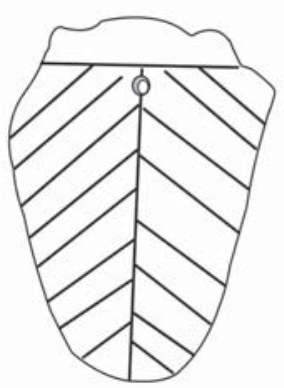

a

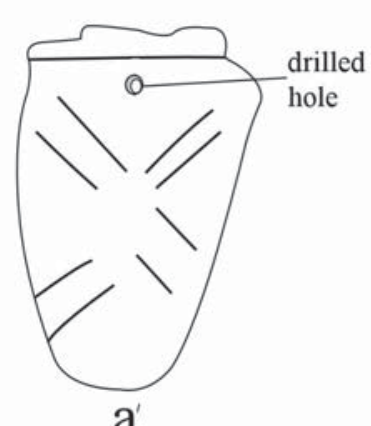

$\mathrm{a}^{\prime}$

Figure 5. Decorative elements on both faces of the ceramic insect effigy from the Wright Plantation site.

In the grog-, grog-hematite-, and bone-tempered decorated sherds from the Wright Plantation site, one is a grog-tempered body sherd that has at least two rows of fingernail punctations below an appliqued node (see Figure 4a). Another body sherd has a single straight incised line (see Table 2). The fine ware sherds in these temper categories include three Hickory Engraved vessel sherds with from 1-3 horizontal engraved lines on the rim, and a body sherd with a small engraved circle element. Another body sherd has a straight engraved line and a red-slipped interior and exterior surface.

The most distinctive ceramic sherd in the assemblage is an insect-shaped effigy that is $46.0 \times 34.3 \mathrm{~mm} \mathrm{x}$ $15.0 \mathrm{~mm}$ in length, width, and thickness (Figure 5ab), and has cut edges at the top of both faces as well as a rounded basal end. Since the effigy is a cast, the temper cannot be ascertained, and thus it is not known which ancestral Caddo component it is associated with at the Wright Plantation site. Both faces of the effigy are decorated with either two sets of diagonal opposed engraved lines and a single vertical engraved line dividing the diagonal opposed lines (Figure 5a) or four sets of two diagonal opposed engraved lines (Figure 5b). There is a partially complete drilled hole on both faces at the top of the engraved designs.

In addition to the ceramic sherds, the TARL collection also has a fragment of an iron knifeprobably from the early $19^{\text {th }}$ century occupation of the site - and one piece of daub. The daub is evidence that there are burned Caddo structures at the Wright Plantation site, either in or near the two extant earthen mounds.

There are also collections from the Wright Plantation site at the National Museum of Natural

History (NMNH) at the Smithsonian Institution (Dorothy Lippert, May 2017 personal collection). The R. King Harris Collection from the site includes ca. 15 ceramic vessel sherds and three arrow points from the Late Caddo period component, along with a large red-slipped and engraved vessel, as well as eight other chipped stone tools. The historic Caddo component at the Wright Plantation site is represented by two gunflints, ca. 15 glass beads, two brass tinklers, two metal buttons, an iron gun main spring, and a brass gun ramrod guide. A second collection from the site was obtained by Joseph Long, and donated to the NMNH in 2002. This collection has projectile points $(n=4)$, one perforator, scrapers $(n=3)$, and flakes $(n=3)$, plus daub $(n=2)$ and ceramic vessel sherds: decorated grog or shell-tempered rims $(n=33)$, redslipped sherds $(\mathrm{n}=33)$, and 259 plain grog- or shell-tempered body sherds. 


\section{Howard Hampton Farm (41RR10)}

The TARL collections include a single vessel from the Howard Hampton Farm (41RR10), which is located a short distance southeast of the Sam Kaufman site (see Figure 1). The vessel is from one of nine ancestral Caddo burials of Late Caddo McCurtain phase age (ca. A.D. 1500-1680) excavated by Hampton and Moore (1936:65). The other vessels that were described as having been placed as funerary offerings in these graves included Avery Engraved bottles $(n=1)$ and deep bowls $(n=1)$, Simms Engraved carinated bowls $(n=1)$, jars $(n=3)$, Nash Neck Banded vessels, Taylor Engraved bottles $(n=1)$, an engraved effigy bowl $(n=1)$, and engraved bowls $(n=1)$. These are typical ceramic vessel types found in Late McCurtain phase contexts on Red River County sites.

SITE NAME OR SITE NUMBER: Howard Hampton Farm (41RR10)

VESSEL NO.: No Number

VESSEL FORM: Jar with a tall rim

NON-PLASTICS AND PASTE: shell

RIM AND LIP FORM: Everted rim and rounded lip

CORE COLOR: F (fired in a reducing environment and cooled in the open air, see Teltser 1993:Figure 2f)

INTERIOR SURFACE COLOR: red

EXTERIOR SURFACE COLOR: red

WALL THICKNESS (IN MM): rim, $5.4 \mathrm{~mm}$; body, $6.0 \mathrm{~mm}$; base, $8.0 \mathrm{~mm}$

INTERIOR SURFACE TREATMENT: burnished

EXTERIOR SURFACE TREATMENT: burnished

HEIGHT (IN CM): 19.1+ (according to Hampton and Moore [1936:65], when complete, the jar stood $27.3 \mathrm{~cm}$ high)

ORIFICE DIAMETER (IN CM): 29.6

DIAMETER AT BOTTOM OF RIM OR NECK (IN CM): 22.8

BASE DIAMETER (IN CM) AND SHAPE OF BASE: $8.3 \mathrm{~cm}$, circular and flat

ESTIMATED VOLUME (IN LITERS): 4.2+ (probably ca. 10.5 liters)

DECORATION (INCLUDING MOTIF AND ELEMENTS WHEN APPARENT): The tall rim has five horizontal engraved lines, three with either upward- or downward-pointing tick marks (Figure 6). Between these sets of lines is a narrow zone filled with horizontal scroll lines and single upper and lower excised tick marks; the horizontal scroll lines are divided by excised brackets with negative S-shaped elements. 


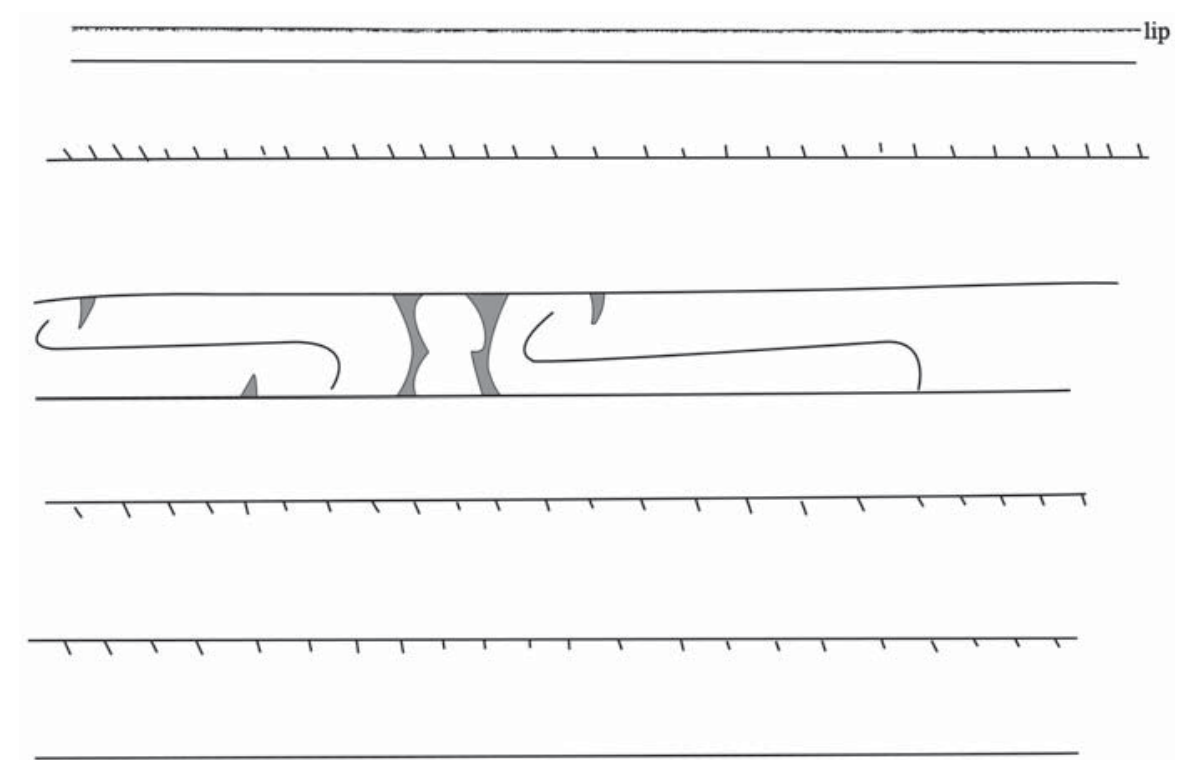

Figure 6. Decorative elements on the rim of an Avery Engraved jar from the Howard Hampton Farm (41RR10).

The vessel body has concentric semi-circular engraved lines, the innermost of which has tick marks; these elements begin along a single horizontal engraved line near the base of the jar body. Surrounding these concentric lines are narrow curvilinear excised zones with spur elements next to zones with hooked arm engraved elements (Figure 7a-e).

PIGMENT USE AND LOCATION ON VESSEL: none

TYPE AND VARIETY (IF KNOWN): Avery Engraved (see Suhm and Jelks 1962:Plate 1a-a')
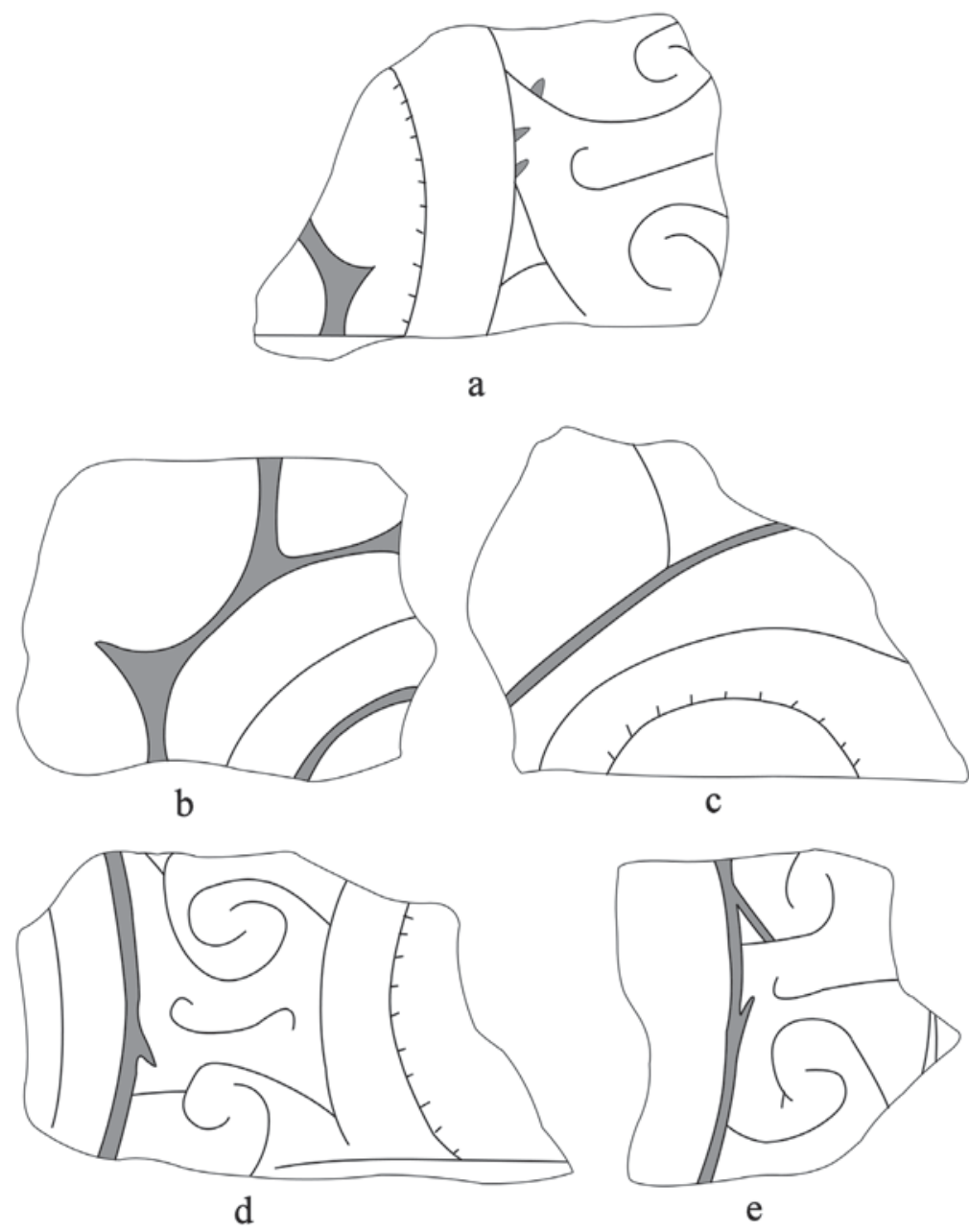

Figure 7. Decorative elements on the body of an Avery Engraved jar from the Howard Hampton Farm (41RR10). 


\section{Sam Kaufman (41RR16)}

The one vessel in the TARL collections from the Sam Kaufman site is a donated vessel from George T. Wright, a local landowner. Correspondence in the TARL files indicates that he did conduct excavations in the late 1930s or 1940 in the East Mound at the Sam Kaufman site, where a number of ancestral burial features were excavated. The Sam Kaufman site is a large ancestral Caddo village and mound center, with extensive cemeteries that began to be exposed along the eroding bank of the Red in the 1940s and 1950s. The burials are from upper and lower cemeteries of post-A.D. 1500 McCurtain phase and ca. A.D. 1700 Historic Caddo age that are both north and east of the principal mound (or East Mound) at the site (see Perttula 2008; Skinner et al. 1969).

The one vessel is a Simms Engraved, var. Darco carinated bowl. This type has notched lips and discontinuous engraved elements with downward-pointing tick marks (Perttula and Selden 2014:Figure $37 \mathrm{a}-\mathrm{b})$. Most have four repeating sets of curvilinear to semi-circular ticked engraved lines. Other early historic Caddo sites with var. Darco vessels include the Hatchel (41BW3) and Clements (41CS25) sites on the Red River and Black Bayou, respectively, and several Kinsloe phase (or Nadaco Caddo) sites in the mid-Sabine River basin in East Texas (see Jones 1968).

SITE NAME OR SITE NUMBER: Sam Kaufman (41RR16)

VESSEL NO.: 129, George T. Wright Collection

VESSEL FORM: Carinated bowl, hubcap form

NON-PLASTICS AND PASTE: shell

RIM AND LIP FORM: Direct rim and rounded lip

CORE COLOR: B (fired and cooled in a reducing environment)

INTERIOR SURFACE COLOR: black

EXTERIOR SURFACE COLOR: black

WALL THICKNESS (IN MM): rim, $4.3 \mathrm{~mm}$; body, $3.8 \mathrm{~mm}$

INTERIOR SURFACE TREATMENT: burnished

EXTERIOR SURFACE TREATMENT: burnished

HEIGHT (IN CM): 7.4

ORIFICE DIAMETER (IN CM): 15.8

DIAMETER AT BOTTOM OF RIM OR NECK (IN CM): 16.4

BASE DIAMETER (IN CM) AND SHAPE OF BASE: $7.4 \mathrm{~cm}$, circular and rounded

ESTIMATED VOLUME (IN LITERS): 0.7 
DECORATION (INCLUDING MOTIF AND ELEMENTS WHEN APPARENT): The rim panel has a single horizontal engraved line with vertical column elements or oval-shaped elements that divide discontinuous curvilinear scroll lines with downward pointing tick marks (Figure 8).

PIGMENT USE AND LOCATION ON VESSEL: red pigment in the engraved lines

TYPE AND VARIETY (IF KNOWN): Simms Engraved, var. Darco

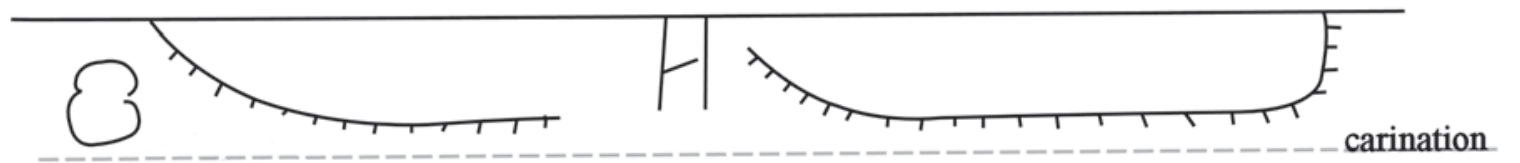

Figure 8. Decorative elements on Simms Engraved, var. Darco carinated bowl from the Sam Kaufman site (41RR16).

\section{Mrs. Joe Skinner/Abe Cox Place}

The Mrs. Joe Skinner vessel is from a site that has not been officially recorded with a State of Texas trinomial. Information in Miscellaneous files for Red River County at TARL indicate that the site was on the Abe Cox Place, two miles northeast of Acworth and one mile southwest of the Red River, and adjoining the Jim Clark place. The Skinner vessel was plowed up sometime before 1931; Mrs. Jim Clark donated the vessel to the University of Texas in May 1931. The Jim Clark place is thought to be associated with the Rowland Clark site (41RR77) in this approximate vicinity (see Perino 1994; Perttula 2016).

SITE NAME OR SITE NUMBER: Mrs. Joe Skinner

VESSEL NO.: 1

VESSEL FORM: Bottle with body knobs

NON-PLASTICS AND PASTE: shell

RIM AND LIP FORM: N/A

CORE COLOR: B (fired and cooled in a reducing environment, see Teltser 1993:Figure 2b)

INTERIOR SURFACE COLOR: dark grayish-brown

EXTERIOR SURFACE COLOR: dark brown

WALL THICKNESS (IN MM): body, $7.1 \mathrm{~mm}$

INTERIOR SURFACE TREATMENT: none

EXTERIOR SURFACE TREATMENT: burnished

HEIGHT (IN CM): 10.0+ 
ORIFICE DIAMETER (IN CM): N/A

DIAMETER AT BOTTOM OF RIM OR NECK (IN CM):

5.1 ; maximum body diameter: $10.9 \mathrm{~cm}$

BASE DIAMETER (IN CM) AND SHAPE OF BASE: 4.8

$\mathrm{cm}$, circular and flat

ESTIMATED VOLUME (IN LITERS): 0.2+

DECORATION (INCLUDING MOTIF AND ELEMENTS WHEN APPARENT): The upper part of the decorative elements on the vessel body are defined by two horizontal engraved lines; there is a single horizontal engraved line just above the vessel base (Figure 9). The main engraved elements on the vessel body - probably repeated four times - are two concentric circles connected to the upper and lower horizontal engraved lines by two or three sets

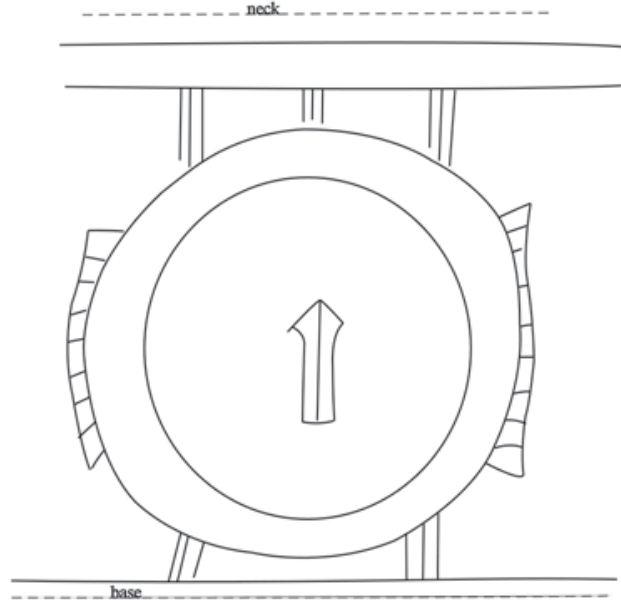

Figure 9. Decorative elements on cf. Avery Engraved bottle donated by Mrs. Joe Skinner.

of three short vertical engraved lines. Inside the center of the concentric circles is a single arrow-shaped zone with a single vertical engraved line, while there are narrow bracket-shaped engraved elements attached to the outer concentric circle (Figure 7). These zones have horizontal hatched lines.

PIGMENT USE AND LOCATION ON VESSEL: none

TYPE AND VARIETY (IF KNOWN): cf. Avery Engraved

\section{Summary and Conclusions}

Ancestral Caddo ceramic vessels recently documented at TARL from the Wright Plantation (41RR7), as well as a small sample of sherds from the site, Howard Hampton Farm (41RR10), Sam Kaufman (41RR16), and the Abe Cox Place (no trinomial) are indicative of two periods of use/burial interments by Caddo peoples. One vessel from the Wright Plantation site is a Crockett Curvilinear olla or shortnecked bottle dating from Early Caddo period times (ca. A.D. 1000-1200), and there are several Hickory Engraved sherds, while the others (all shell-tempered) are associated with Late Caddo, McCurtain phase burial features dating probably after ca. A.D. 1500, and possibly as late as ca. A.D. 1700-1720. These include a plain shell-tempered jar, Avery Engraved jars and bottles, a Simms Engraved, var. Darco carinated bowl. and a grog-tempered Wilder Engraved, var. Wilder bottle from the Wright Plantation site; this vessel likely was made by a Caddo potter in a $16^{\text {th }}$ century Titus phase village in the Big Cypress or Sabine River basins in East Texas (see Perttula 2012:Figure 13-1), locales where Wilder Engraved vessels were common funerary offerings. One early Historic Hatinu Engraved sherd is in the assemblage from the Wright Plantation site.

\section{Acknowledgments}

I thank Marybeth Tomka (Texas Archeological Research Laboratory, The University of Texas at Austin) for access to the vessels from these Red River County sites. Thanks also to Dorothy Lippert (NMNH) for providing information about collections from the Wright Plantation site at the Smithsonian Institution. Lance Trask prepared the figures in this article. 


\section{References Cited}

Flynn, P.

1976 A Study of Red-Filmed Pottery from the Clement Site (Mc-8), McCurtain County, Oklahoma. Bulletin of the Oklahoma Anthropological Society 25:127-134.

Hampton, H. and G. Moore

1936 A Burial Site in Northeastern Red River County. Central Texas Archeologist 2:64-68.

Jones, B. C.

1968 The Kinsloe Focus: A Study of Seven Historic Caddoan Sites in Northeast Texas. Master's thesis, Department of Anthropology, University of Oklahoma, Norman.

Perino, G.

1994 Archaeological Research at the Rowland Clark Site (41RR77), Red River County, Texas. Journal of Northeast Texas Archaeology 4:3-42.

Perttula, T. K.

2008 The Archeology of the Roitsch Site (41RR16), an Early to Historic Caddo Period Village on the Red River in Northeast Texas. In Collected Papers from Past East Texas Archeological Society Summer Field Schools, edited by T. K. Perttula, pp. 313-628. Special Publication No. 5. Texas Archeological Society, San Antonio.

2012 The Character of Fifteenth- to Seventeenth-Century Caddo Communities in the Big Cypress Creek Basin of Northeast Texas. In The Archaeology of the Caddo, edited by T. K. Perttula and C. P. Walker, pp. 363-410. University of Nebraska Press, Lincoln.

2016 Ancestral Caddo Ceramic Vessels from the Wright Plantation (41RR7) and Rowland Clark (41RR77) Sites in the Harris Collection at the National Museum of Natural History, Smithsonian Institution. Journal of Northeast Texas Archaeology 70:115-119.

Perttula, T. K. and R. Z. Selden, Jr.

2014 Ancestral Caddo Ceramics in East Texas. Journal of Northeast Texas Archaeology 48:9-58.

Prikryl, D. J.

2008 The 1991 and 1992 Texas Archeological Society Field School Excavations at the Fasken Site (41RR14), Red River County, Texas. In Collected Papers from Past Texas Archeological Society Summer Field Schools, edited by T. K. Perttula, pp. 125-171. Special Publication No. 5. Texas Archeological Society, San Antonio.

Skinner, S. A., R. K. Harris, and K. M. Anderson (editors)

1969 Archaeological Investigations at the Sam Kaufman Site, Red River County, Texas. Contributions in Anthropology No. 5. Department of Anthropology, Southern Methodist University, Dallas.

Suhm, D. A. and E. B. Jelks (editors)

1962 Handbook of Texas Archeology: Type Descriptions. Special Publication No. 1, Texas Archeological Society and Bulletin No. 4, Texas Memorial Museum, Austin.

Teltser, P. A.

1993 An Analytic Strategy for Studying Assemblage-Scale Ceramic Variation: A Case Study from Southeast Missouri. American Antiquity 58(3):530-543. 